\title{
A Parametric Study of Confinement Effects to the Interaction Diagram of P-M for High-Strength Concrete Columns
}

\author{
Nur Fithriani F. Cholida ${ }^{1}$, Antonius ${ }^{2}$ and F. Ni'am ${ }^{2}$ \\ ${ }^{1}$ Graduate Student of Civil Engineering,Universitas Islam Sultan Agung, Semarang, Indonesia \\ ${ }^{2}$ Department of Civil Engineering, Universitas Islam Sultan Agung, Semarang, Indonesia \\ $1^{\text {st }}$ author: tiafithria@gmail.com \\ $2^{\text {nd }}$ author: faiqun@unissula.ac.id \\ *corresponding author: antonius@unissula.ac.id
}

(Received: April 2 $2^{\text {nd }}, 2018$; Accepted: April 12 $\left.{ }^{\text {th }}, 2018\right)$

\begin{abstract}
In reinforced concrete columns design, P-M interaction diagram is used as axial load control and column bending without taking into account the effect of lateral reinforcement bars. Design principles that ignore the effect of reinforcement bars will result in low value of actual axial capacity of column. This paper presents the effect of lateral reinforcement with a case study of square-sectional columns on highstrength concrete. The equation of unconfined concrete strength enhancement is based on Mander, Legeron, Imran, Antonius and Muguruma models. The reviewed parameters include compressive strength of concrete, reinforcement configuration, and spacings of confinement. The result of the analysis is a comparison of P-M diagram based on confinement models. It shows that confinement significantly influences axial capacity of column, yet it has a certain collapse point at point $\mathrm{P}=0$ in all models. This is caused by longitudinal reinforcement system. Configuration of reinforcement, spacing and confinement models greatly affects the collapse behavior of column, whether the collapse is classified as compressive collapse or tensile collapse based on the P-M diagram.
\end{abstract}

Keywords: $P$-M diagram, confinement models, reinforcement configuration, confinement

\section{INTRODUCTION}

Recently, high-strength concrete (HSC) $\left(f_{c}{ }^{\prime} \geq 50 \mathrm{MPa}\right)$ has been the primary choice for construction design due to its highly favorable properties in building structures, such as cracking and high durability. Various studies on HSC structures are also continuously developed to produce a comprehensive design equation [1-3]. However, HSC has brittle properties and premature cover-spalling process. Modification design equations has been proposed by researchers $[4,5]$ to anticipate brittling and premature cover-spalling process.

The installation of lateral reinforcement as a curb on the core cross-section of column is intended for lateral stress enhancement to increase the strength and slows down the collapse process of confined concrete column so that it becomes more ductile. The larger the volumetric ratio and tighter the lateral rebars are installed, the strength and ductility of concrete columns will be higher as well. Mander et al. (1988) [6], uses the equation of unconfined concrete strength enhancement based on the following equation:

$$
f_{c c}=f_{c}+4.1 f_{2}
$$


In design of column, the structural safety requirements are usually controlled through axial force interaction towards moment diagram or P-M diagram. The calculation of axial force $(\mathrm{P})$ does not include confinement, which is calculated by the following equation [7]:

$$
P_{o}=0,85 f_{c}^{\prime}\left(A_{g}-A_{c}\right)+A_{s} f_{y}
$$

Confinement bar installed within a certain volumetric ratio will increase axial capacity of column, which is represented by the value of $f_{2}$ in equation (1). The calculation that is based on equation (2) results in under estimation of actual axial capacity of column. If the confinement reinforcement is taken into account it will lead to significant changes in the $\mathrm{P}-\mathrm{M}$ diagram. If the use of reinforcement bars is taken into account, the accuracy of the used confinement model should be questioned, considering that there has been certain confinement models developed for normal concrete up to high-strength concrete.

This paper evaluates the influence of confinement's contribution in column design, where the effect of confinement bars in estimating axial capacity of column based on the developed confinement models is taken into account, P-M interaction diagram design is based on confinement models. The assumption in this analysis is the calculation of concrete column capacity is based on equation (1), the installed longitudinal reinforcement mounted in the column is based on under-reinforced system. The reviewed variables in this analysis are compressive strength of concrete, characteristics of the confinement including volumetric ratio, yield stress, spacings and configurations.

\section{CONFINEMENT MODELS}

Table 1 presents the developed confinement models. Confinement model by Mander is basically derived from the test results of concrete columns without fiber and having a normal strength of concrete compressive strength $\left(f_{c}^{\prime} \approx 30 \mathrm{MPa}\right)$. Stress-strain models are proposed to have one equation as shown in Table 1. The stress-strain equations developed by Imran et al. [8] is based on the results of triaxial testing (active confinement) by using concrete quality between 60 and $90 \mathrm{MPa}$. The applied lateral load varies from 0 to $0.4 f_{c}^{\prime}$. this confinement model can be applied to normal and high quality concrete. The confinement model proposed by Muguruma et al. [9] is based on experimental results of concrete quality between 20-160 MPa. Therefore, the stress and strain model can be applied to both high and normal quality concrete. In addition, this model can be used to analyse confined concrete with normal yield stress and high yield stress. The Legeron \& Paultre model [10] is developed for confined square concrete, based on experiment of 50 pieces high quality concrete tested against concentric loading. The specimens used to develop the model are 30 pieces of $235 \times 235 \times 1400 \mathrm{~mm}$ confined concrete column and 20 pieces of $225 \times 225 \times 715 \mathrm{~mm}$ confined concrete column. Specimens in the first group were comprised of concrete with compressive strength between 60-120 MPa, and lateral reinforcement with yield stress between 400-800 MPa. Specimens in the second group were comprised of concrete with compressive strength between 60-120 MPa, and lateral reinforcement with yield stress between 400-800 MPa. Based on the test data, it can be concluded that the proposed model of Legeron \& Paultre can be applied to normal quality concrete and high quality confined concrete. Antonius et al. [11] proposed confinement models for both high quality concrete and normal quality concrete, in which the model was developed based on the square and circular column test results. Lateral stress due to confinement bar depends on characteristics of confinement bar and effective lateral stress that is adopted from effectiveness of confinement concept, which is based on Mander proposal. 
Table 1. Confinement models

\begin{tabular}{|c|c|c|}
\hline Model & Peak stress and peak strain & Parameter equations \\
\hline Mander et al. (1988) & $\begin{array}{c}\frac{f_{c c}^{\prime}{ }_{c o}}{f^{\prime}{ }_{c o}}=-1.254+2.254 \sqrt{1+\frac{7.94 f_{l}}{f^{\prime}{ }_{c o}}}-2 \frac{f_{l}}{f^{\prime}{ }_{c o}} \\
\varepsilon_{c c}=\varepsilon_{c o}\left[1+5\left(\frac{f^{\prime}{ }_{c c}}{f^{\prime}{ }_{c o}}-1\right)\right]\end{array}$ & $\begin{array}{c}x=\frac{\varepsilon_{c}}{\varepsilon_{c c}} \quad r=\frac{E_{c}}{E_{c}-E_{\mathrm{sec}}} \\
E_{c}=5000 \sqrt{f_{c o}^{\prime}} \mathrm{MPa} \\
E_{\mathrm{sec}}=\frac{f_{c c}^{\prime}}{\varepsilon_{c c}}\end{array}$ \\
\hline Imran et al. [8] & $\begin{array}{c}K=\frac{f_{c c}^{\prime}{ }^{\prime}}{f_{c}^{\prime}}=1+4,4 \frac{f_{2}}{f_{c}^{\prime}} \\
\varepsilon_{c c}{ }^{\prime}=\mathrm{K} \varepsilon_{c}{ }^{\prime}\end{array}$ & $\begin{array}{c}\varepsilon_{c}^{\prime}=0,003 \\
\mathrm{Z}=\frac{0,15 \cdot \mathrm{f}_{\mathrm{cc}}^{\prime}}{\varepsilon_{0,85}-\varepsilon_{\mathrm{cc}}{ }^{\prime}}\end{array}$ \\
\hline Muguruma et. al. [9] & $\begin{array}{c}\bar{\sigma}_{m}=\left(1+49 . C_{c}\right) f_{c}^{\prime} \\
\bar{\varepsilon}_{m}=\left(1+341 . C_{c}\right) \varepsilon_{m} \\
C_{c}=0.313 \rho \frac{\sqrt{\mathrm{f}_{\mathrm{yh}}}}{\mathrm{f}_{\mathrm{c}}{ }^{\prime}}\left(1-0.5 \frac{\mathrm{s}}{\mathrm{w}}\right)\end{array}$ & $\begin{array}{c}\mathrm{E}_{\mathrm{i}}=22700 \sqrt{\mathrm{f}_{\mathrm{c}}{ }^{\prime} / 19.6} \\
\varepsilon_{\mathrm{m}}=0.0013\left(1+f c^{\prime} / 98.6\right)\end{array}$ \\
\hline $\begin{array}{c}\text { Legeron \& Paultre } \\
{[10]}\end{array}$ & $\begin{array}{c}\frac{f_{c c}}{f_{c o}}=1+3\left(\frac{f_{l e}}{f_{c o}}\right)^{0.9} \\
\varepsilon_{c c}=\varepsilon_{c o}+0.2\left(\frac{f_{l e}}{f_{c o}}\right)^{1.7}\end{array}$ & $\begin{array}{c}k=\frac{E_{c}}{E_{c}-\left(f_{c c} / \varepsilon_{c c}\right)} \\
k_{1}=\frac{\ln 0.5}{\left(\varepsilon_{c 50 c}-\varepsilon_{c c}\right)^{k_{2}}} \\
k_{2}=0.4+15\left(f_{l e} / f_{c o}\right)^{1.3}\end{array}$ \\
\hline Antonius et al. [11] & $\begin{array}{c}\frac{f_{c c}^{\prime}}{f_{c o}^{\prime}}=\left(\frac{f_{l}}{f_{c o}^{\prime}}-0.327\right)+\sqrt{1.7606+16.1714 \frac{f_{l}}{f_{c o}^{\prime}}} \\
\varepsilon_{c c}^{\prime}=\varepsilon_{c o}^{\prime}[1.94(K-1)+1]\end{array}$ & $\begin{array}{l}\varepsilon_{c o}{ }^{\prime}=0,0004 \cdot\left(f c^{\prime}{ }_{o}\right)^{0.45} \\
\varepsilon_{85 c}=\varepsilon^{\prime}{ }_{c c}+3 \cdot 10^{-5} \cdot e^{3.2 K}\end{array}$ \\
\hline
\end{tabular}

\section{CASE STUDY}

P-M interaction diagram with the influence of confinement is then evaluated by case study of cross section column with reinforcement configuration of $\mathrm{A}, \mathrm{B}$ and $\mathrm{C}$ as shown in Fig. 1. The cross-sectional dimension is $300 \times 300 \mathrm{~mm}$, compressive strengths $\left(f^{\prime}{ }_{c}\right)$ are 50 and $70 \mathrm{Mpa}$, cover $=40 \mathrm{~mm}$ (according to SNI requirement), longitudinal reinforcement bar with $16 \mathrm{~mm}$ diameter and yield stress $\left(f_{y l}\right)$ of $400 \mathrm{Mpa}$. Confinement bar with $10 \mathrm{~mm}$ diameter, yield stress $\left(f_{y l}\right)$ of 400 Mpa and confinement bars spaced in vary by 100, 150 and $200 \mathrm{~mm}$. Moment design equations for high quality concrete are used in calculating moment [12].

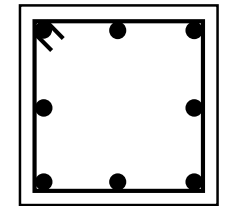

Configuration A

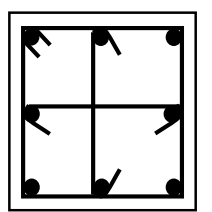

Configuration B

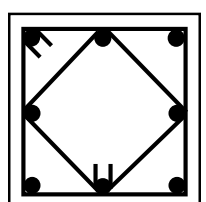

Configuration $\mathrm{C}$

Fig. 1. Reinforcement configurations 


\section{RESULTS AND DISCUSSION}

The analysis results of P-M interaction diagram based on confinement models are shown in the figure below. Overall, it appears that the confinement bar increases axial force in column (P), this applies for all constraint models. In all cases, there is no difference in moment capacity between unconfined and confined columns. This is due to the use of under-reinforced longitudinal reinforcement system.

\section{Configuration of A}

The comparison of P-M interaction diagram of configuration of A towards P-M diagram interaction of high quality concrete columns with different spacings between bars are shown in Fig. 2 and 3. The value of $\mathrm{P}$ in the figure appears to vary, depends on the value of $\mathrm{K}$ in each confinement models. Axial capacity of columns is seen increasing with tighter space in confinement bars. The $\mathrm{P}$ values between confinement models are relatively close to each other at a balanced point area. The curve from balance point to tension failure area until $\mathrm{P}=0$ is relatively coherent.

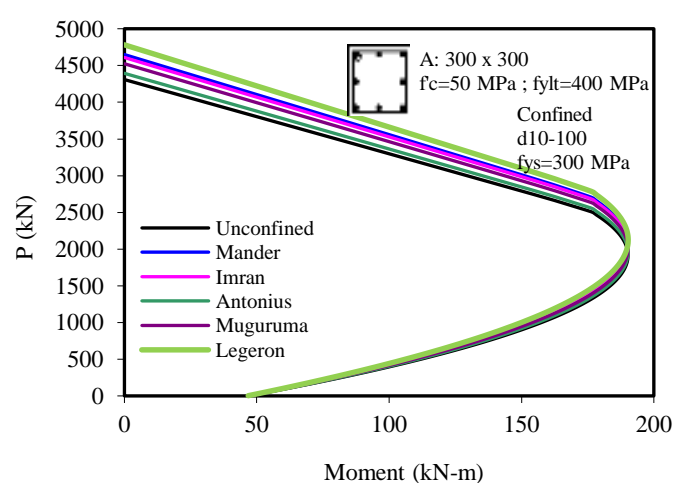

(a) $\mathrm{s}=100 \mathrm{~mm}$

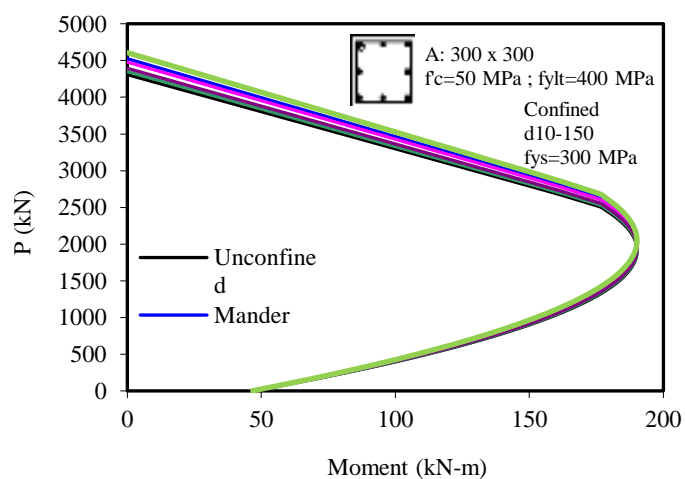

(b) $\mathrm{s}=150 \mathrm{~mm}$

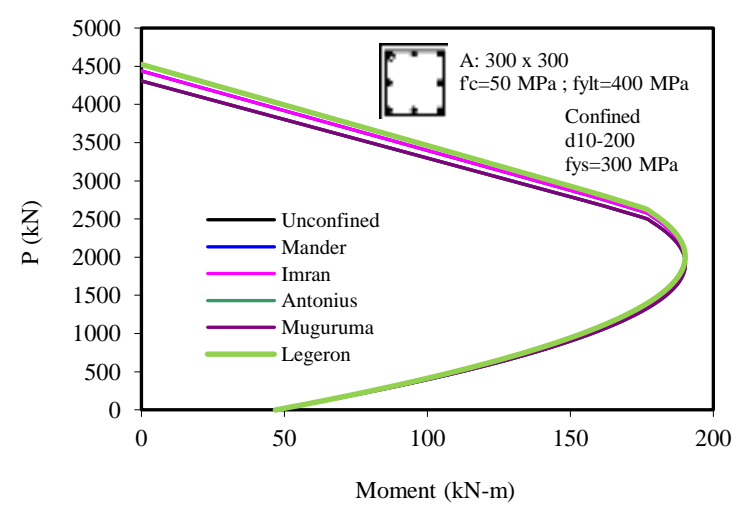

(c) $\mathrm{s}=200 \mathrm{~mm}$

Fig. 2. Configuration of $\mathrm{A}, f_{c}^{\prime}=50 \mathrm{MPa}$ 


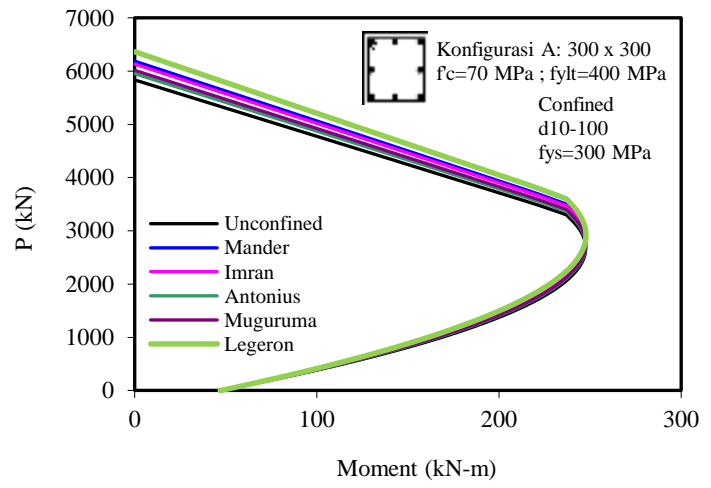

(a) $\mathrm{s}=100 \mathrm{~mm}$

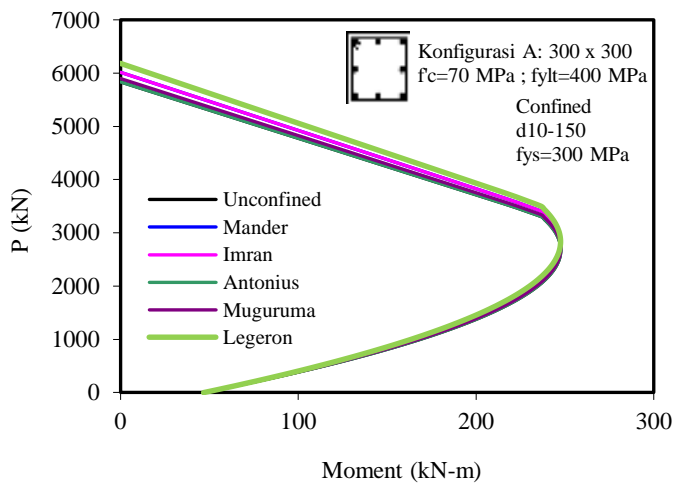

(b) $\mathrm{s}=150 \mathrm{~mm}$

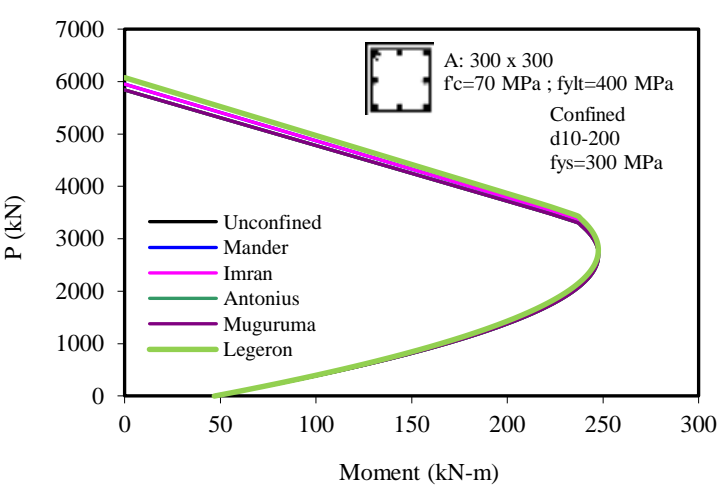

(c) $\mathrm{s}=200 \mathrm{~mm}$

Fig. 3. Configuration of $\mathrm{A}, f_{c}{ }^{\prime}=70 \mathrm{MPa}$

\section{Configuration of $B$}

Configuration $\mathrm{B}$ has a different $\mathrm{P}-\mathrm{M}$ curve behavior than the above configuration $\mathrm{A}$. According to Fig. 4 and 5, the value of $\mathrm{P}$ in configuration $\mathrm{B}$ that is based on prediction of confinement models appears to be higher than the value of $\mathrm{P}$ in unconfined concrete. Another phenomenon that occurs, is that if the spacings for each reinforcement is tighter, the values of $\mathrm{P}$ and $\mathrm{M}$ will be higher than the values of $\mathrm{P}$ and $\mathrm{M}$ in unconfined columns. This however, does not apply to point $\mathrm{P}=0$ due to under reinforced longitudinal reinforcement system.

\section{Configuration of $\mathbf{C}$}

Configuration $\mathrm{C}$ has a similar P-M diagram behavior with configuration $\mathrm{B}$ above. This happens due to volumetric confinement ratio between two configurations that are not significantly different. Based on Fig. 6 and 7, the P value that is based on predicted confinement models appear to be higher than the $\mathrm{P}$ value of unconfined concrete. Another behavior that occured is that if the confinement bars is more tightly spaced, the values of $\mathrm{P}$ and $\mathrm{M}$ will be higher than $\mathrm{P}$ and $\mathrm{M}$ values of unconfined concrete. In extreme bending area $(\mathrm{P}=0)$, all confined and unconfined moments from all models are equal due to under-reinforced reinforcement system. 


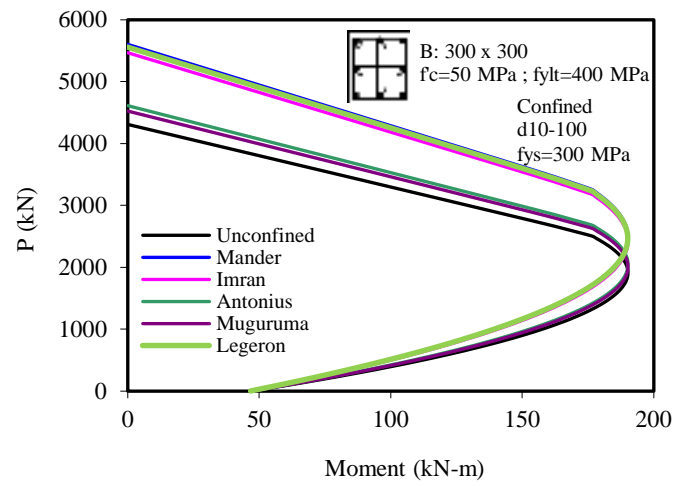

(a) $\mathrm{s}=100 \mathrm{~mm}$

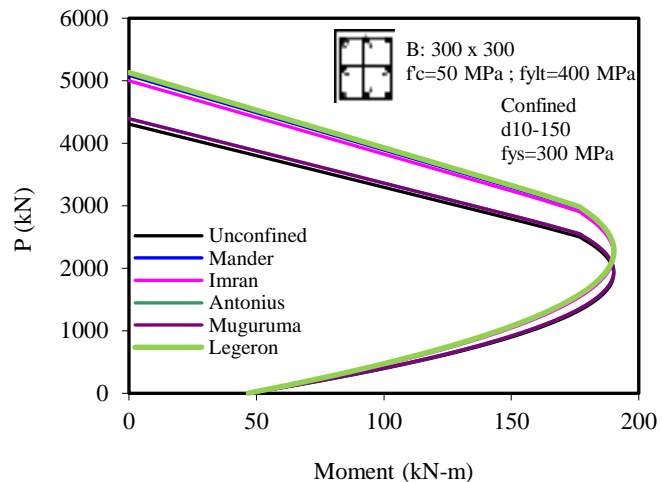

(a) $\mathrm{s}=150 \mathrm{~mm}$

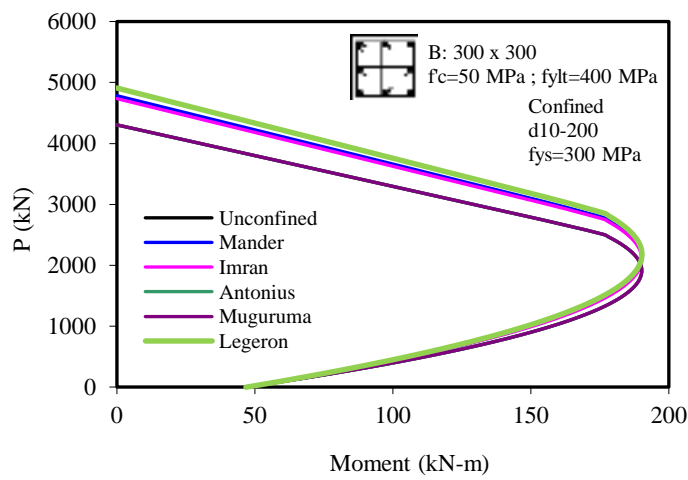

(c) $\mathrm{s}=200 \mathrm{~mm}$

Fig. 4. Configuration of $\mathrm{B}, f_{c}{ }^{\prime}=50 \mathrm{MPa}$

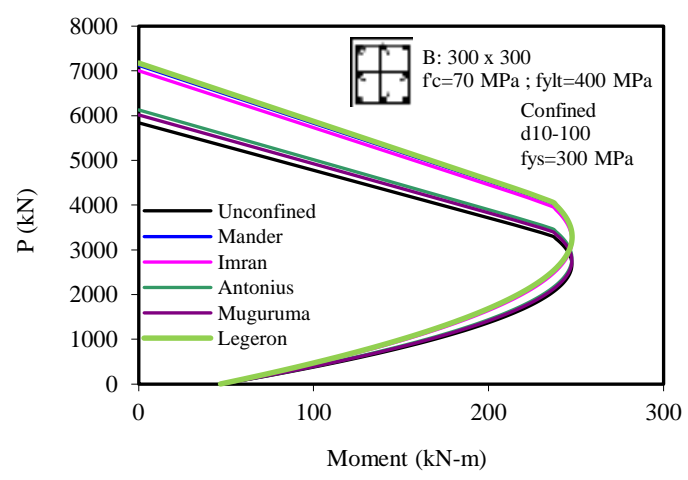

(a) $\mathrm{s}=100 \mathrm{~mm}$

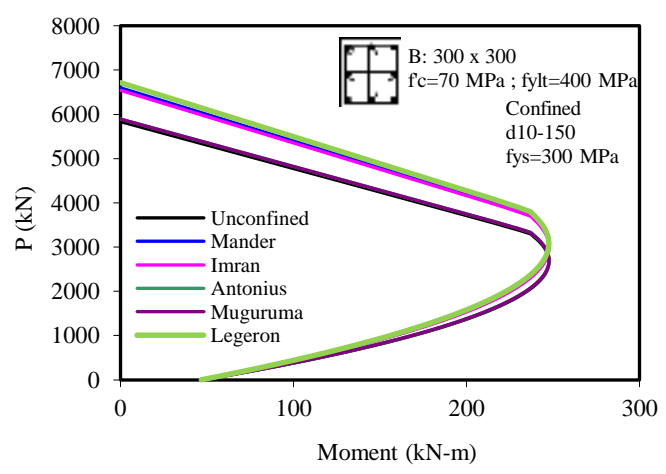

(b) $\mathrm{s}=150 \mathrm{~mm}$

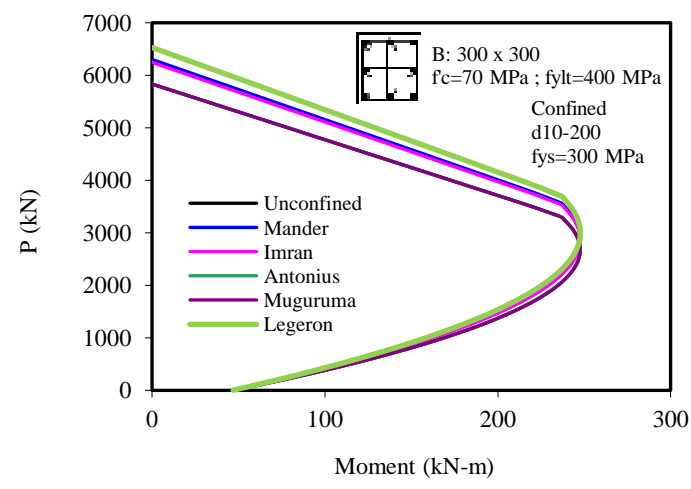

(c) $\mathrm{s}=200 \mathrm{~mm}$

Fig. 5. Configuration of $\mathrm{B}, f_{c}{ }^{\prime}=70 \mathrm{MPa}$ 


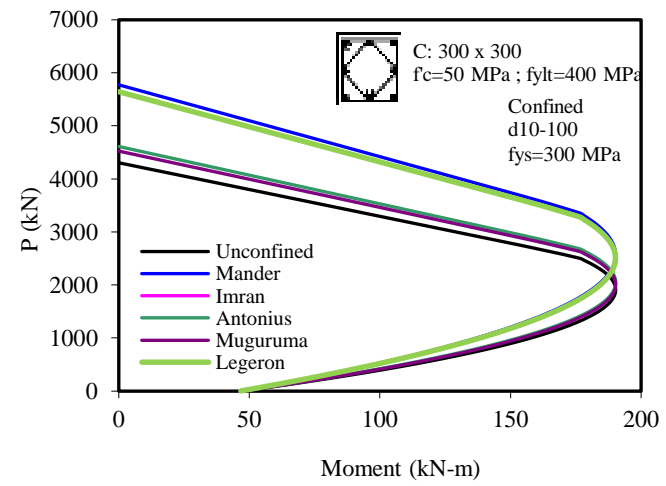

(a) $\mathrm{s}=100 \mathrm{~mm}$

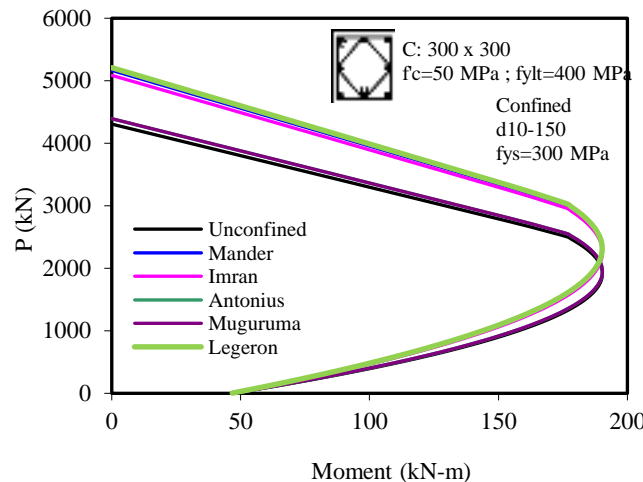

(b) $\mathrm{s}=150 \mathrm{~mm}$

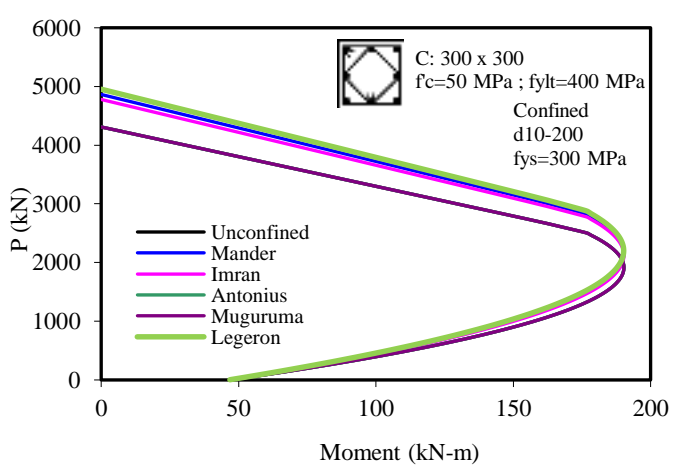

(c) $\mathrm{s}=200 \mathrm{~mm}$

Fig. 6. Configuration of $\mathrm{C}, f_{c}{ }^{\prime}=50 \mathrm{MPa}$

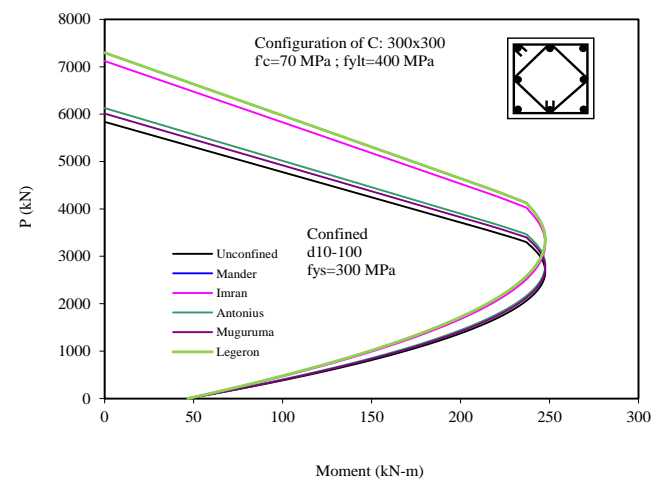

(a) $\mathrm{s}=100 \mathrm{~mm}$

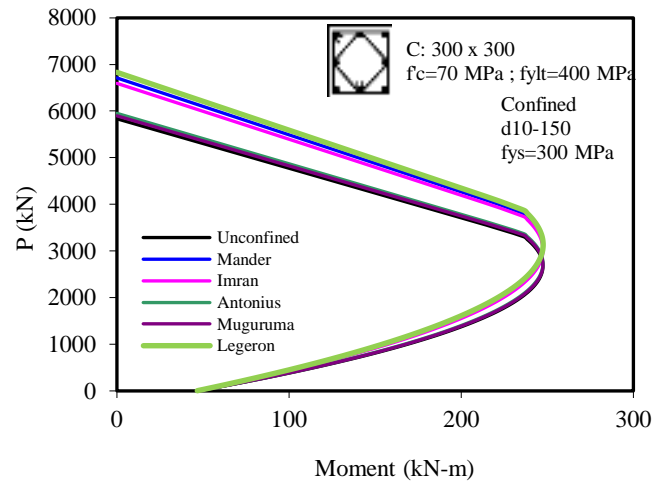

(b) $\mathrm{s}=150 \mathrm{~mm}$

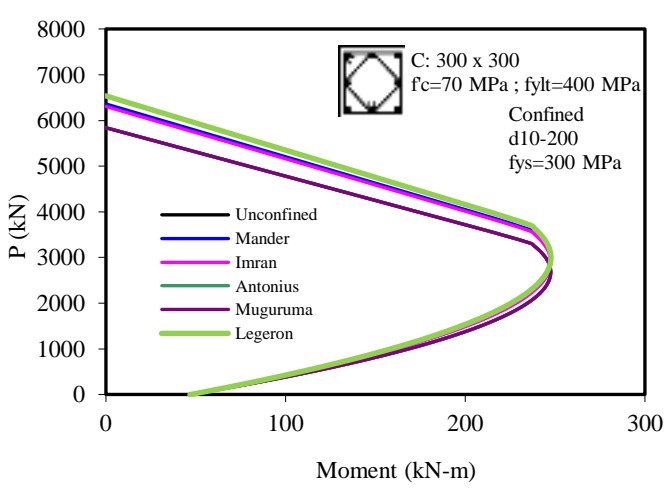

(c) $\mathrm{s}=200 \mathrm{~mm}$

Fig. 7. Configuration of $\mathrm{C}, f_{c}{ }^{\prime}=70 \mathrm{MPa}$ 


\section{CONCLUSIONS}

1. Confinement bar has an important role in increasing axial capacity of column. The applied lateral stress causes the concrete core to remain stable and delays the collapse of column, where axial force of column will also consequently increase.

2. Volumetric ratios and spacings of confinement bars have a dominant role in increasing axial capacity of column. Confinement bars with higher volumetric ratio and tighter spacings will result in higher axial capacity of column.

3. Enhanced strength of confined concrete $(K)$ based on Legeron's proposed equation is the highest compared to other model equations, especially for configuration $\mathrm{A}$. The proposed equation of Mander model is the highest prediction for $\mathrm{K}$ value for $100 \mathrm{~mm}$ and $150 \mathrm{~mm}$ spacing installations. However, the model proposed by Legeron has the highest predicted $\mathrm{K}$ value for wide spacing installation $(200 \mathrm{~mm})$. This behavior applies to the configuration columns A, B and C.

4. All confinement models in P-M interaction diagram have significant influence in increasing axial capacity of column to balance point. However, below the balance point (tension failure area), the behavior of P-M diagram is relatively close for both confined and unconfined concrete columns. This shows that the reinforcement bar does not have substantial effect if the column behavior is in tension failure area, especially for cross-section configuration A

\section{REFERENCES}

[1] Razvi, S.R. and Saatcioglu, M. (1999), Confinement Model for High-Strength Concrete, Journal of Structural Engineering, 125(3), pp. 281-289.

[2] Antonius and Imran, I. (2012), Experimental Study of Confined Low, Medium and High-Strength Concrete Subjected to Concentric Compression, ITB Journal of Engineering Science, 44(3), 252-69.

[3] Bae, S. \& Bayrak, O. (2003), Early Cover Spalling in High-Strength Concrete Columns, Journal of Struct. Eng. ASCE, 129(3), pp. 314-323.

[4] Nishiyama, M. (2009), Mechanical Properties of Concrete and Reinforcement-State-of-the-art Report on HSC and HSS in Japan; Journal of Advanced Concrete Technology, 7(2), pp. 157-182.

[5] Mander, J.B.; Priestley, M.J.N. and Park, R. (1988); Theoritical Stress-Strain Model for Confined Concrete; Journal of Struc. Eng. ASCE, V.114, No.8, August, pp.1804-1824.

[6] Badan Standardisasi Nasional (2013); Requirements of Structural Concrete for Building (in Indonesian), SNI 2847-2013.

[7] Imran, I., Suharwanto, Moestopo, M. and Brahmantyo, D. (2001), Stress-Strain Response of Confined High Strength Concrete, Journal of Civil Eng. ITB, 8(3), pp.135-144.

[8] Muguruma, H.; Nishiyama, M. and Watanabe, F. (1993); Stress-strain Curve Model for Concrete with a Wide-Range of Compressive Strength; Proc. of High-Strength Concrete Conf., Norway, pp.314-321.

[9] Legeron, F. dan Paultre, P. (2003); Uniaxial Confinement Model for Normal and High-Strength Concrete Columns; Journal of Struc. Eng. ASCE, V.129, No.2, pp.241-252.

[10] Antonius, I. Imran and P. Setiyawan (2017); On the Confined High-Strength Concrete and Need of Future Research; Procedia Engineering, Vol. 171, pp.121-130.

[11] Cholida, Nur F.F. (2018); The Analysis of Axial and Flexural Capacities on the Columns Structures Considered Confinement, Master Thesis, Civil Eng. Master Program, Universitas Islam Sultan Agung (in Indonesian)..

[12] Antonius (2012); Flexural Capacities and Stress Block Parameters for High-Strength Concrete Columns, Dinamika Teknik Sipil UMS, Akreditasi No. 110/DIKTI/Kep/2009, Vol.12(3), September, pp.201-206. 